\title{
DAMPAK SUBSIDI TERHADAP HARGA GABAH DAN KESEJAHTERAAN PETANI
}

\section{THE IMPACT OF SUBSIDY ON THE PRICES OF RICE AND FARMER WELFARE}

\author{
Cici Aulia Permata Bunda* ${ }^{*}$ Octaviana Helbawanti ${ }^{2}$, dan Faqihuddin ${ }^{3}$ \\ ${ }^{1}$ Jurusan Agribisnis, Fakultas Pertanian, Universitas Siliwangi, Tasikmalaya \\ *E-mail corresponding: ciciaulia@unsil.ac.id
}

\begin{abstract}
ABSTRAK
Kebijakan subsidi yang telah diberlakukan pada sektor pertanian di Indonesia bertujuan untuk mengurangi biaya produksi usahatani agar pasokan bahan pangan bagi masyarakat tetap terjaga. Penelitian ini bertujuan untuk menganalisis bagaimana dampak subsidi terhadap harga gabah dan bagaimana pula dampaknya pada kesejahteraan petani. Data yang digunakan dalam penelitian ini adalah data time series tahun 2010-2020 yakni berupa data anggaran belanja pemerintah Indonesia untuk subsidi (energi dan non energi), harga Gabah Kering Pungut (GKP) di tingkat petani dan Nilai Tukar Petani (NTP) sebagai salah satu indikator kesejahteraan petani. Hasil analisis regresi linear berganda menunjukkan bahwa subsidi energi dan non energi berdampak pada harga GKP baik secara parsial maupun secara simultan dengan koefisien determinasi 73 Persen. Selanjutnya diketahui pula bahwa secara parsial subsidi energi berpengaruh terhadap harga GKP namun tidak berpengaruh terhadap NTP, meskipun secara simultan memiliki pengaruh terhadap NTP dengan koefisien determinasi sebesar 63 persen. Dengan melihat besaran koefisien determinasi tersebut kita memperoleh gambaran bahwa kebijakan subsidi memiliki dampak yang lebih besar terhadap harga GKP daripada dampaknya terhadap NTP. Hal ini memang sejalan dengan tujuan awal subsidi yaitu mengurangi biaya produksi bukan pada peningkatan pendapatan dan kesejahteraan petani. Padahal kesejahteraan petani merupakan salah satu faktor penting dalam mendukung proses pembangunan pertanian. Oleh karena itu, penulis memandang bahwa kebijakan subsidi yang bersifat subsidi input perlu disertai dengan kebijakan memberikan insentif pendapatan bagi petani.
\end{abstract}

Kata kunci: Insentif Pendapatan, Kesejahteraan Petani, Subsidi Energi, Subsidi Non Energi.

\section{ABSTRACT}

The subsidy policy that has been implemented in the agricultural sector in Indonesia aims to reduce farm production costs so that the food supply for the community is secured. This study aims to analyze how the impact of subsidies on the price of rice and how it impacts farmers' welfare. The data used in this study are time series data for the years 2010-2020 including data on the Indonesian government budget for subsidies (energy and non-energy), the price of rice (Unhulled Rice) at the farmer level and the Farmer Exchange Rate (FER) as one of the farmer welfare indicators. The results of multiple linear regression analysis show that energy and nonenergy subsidies have an impact on the rice price either partially or simultaneously with a determination coefficient of 73 percent. Furthermore, it is also known that partially energy subsidies affect the price of rice but have no effect on FER, although simultaneously it has an effect on FER with a coefficient of determination of 63 percent. By looking at the value of the determination coefficient, we get an overview that the subsidy policy has a greater impact on the price of rice than FER. This is in line with the original objective of subsidies, it is reducing production costs, not increasing farmers' income and welfare. In fact, the farmers welfare is an 


\section{DAMPAK SUBSIDI TERHADAP HARGA GABAH}

DAN KESEJAHTERAAN PETANI

Cici Aulia Permata Bunda, Octaviana Helbawanti, dan Faqihuddin

important factor in supporting the agricultural development process. Therefore, the authors view that a subsidy policy that is input subsidies needs to be accompanied by a policy of providing income incentives for farmers.

Keywords: Energy Subsidy, Farmers Welfare, Input Subsidy, Non-Energy Subsidy

\section{PENDAHULUAN}

Ketahanan pangan menjadi salah satu tujuan global yang tercantum dalam Sustainable Development Goals (SDGs) yakni No Hunger, oleh karenanya setiap negara mengeluarkan kebijakannya masing-masing. Ketahanan pangan dapat ditengarai dengan jumlah produksi bahan pangan yang sesuai dengan jumlah yang dibutuhkan oleh masyarakat serta harganya terjangkau. Dalam mencapai kondisi tersebut, kebijakan subsidi masih menjadi pilihan pemerintah Indonesia saat ini. Dengan pemberian subsidi pupuk dimaksudkan untuk mengurangi beban biaya produksi pangan, sehingga para petani terdorong untuk senantiasa melaksanakan usahataninya. Pasokan produksi yang cukup dan berkelanjutan tentu berakibat pada harga bahan pangan pada tingkat konsumen (sesuai dengan hukum penawaran) akan menjadi lebih murah. Terjangkaunya harga bahan pangan inilah yang akan menciptakan kondisi ketahanan pangan di suatu negara.

Dalam outlook APBN Indonesia belanja subsidi dibagi menjadi 2 (dua) yakni subsidi energi (meliputi subsidi BBM dan Listrik) dan subsidi non energi. Subsidi non energi meliputi subsidi pangan, subsidi pupuk, subsidi benih, Public Service Obligation (PSO), Subsidi kredit program, Subsidi Pajak. Dari sekian jenis subsidi yang paling besar adalah subsidi untuk pupuk. Selama kurun waktu 2015-2018 rata-rata sebesar 45,4 persen dari total anggaran subsidi. Data tahun 2019 menunjukkan besaran subsidi pupuk adalah $\mathrm{Rp} 37,1$ Trilyun (Andini 2020). Besarnya anggaran subsidi pupuk tidak akan benar-benar mencapai tujuannya jika tidak ditindaklanjuti dengan metode penyaluran yang tepat. Penyaluran yang kurang tepat akan menyebabkan subsidi tersebut menjadi tidak efektif baik dari aspek harga, tempat, waktu maupun jumlah (Mulyadiana dkk. 2018).

Beberapa hal yang juga perlu menjadi perhatian kita juga yakni bahwa terkadang subsidi pupuk hanya berdampak signifikan pada efisiensi dan produktivitas usahatani skala kecil namun tidak berdampak pada skala menengah dan besar (Nasrin dkk. 2018). Adakalanya juga subsidi pupuk justru memicu penggunaan pupuk dengan dosis yang berlebih oleh petani karena merasa harga pupuk murah, padahal sesuai dengan hukum kenaikan hasil yang semakin berkurang (law of diminishing return) hal 
ini tentu akan menyebabkan produktivitas yang menurun (Hussain dkk. 2018).

Namun demikian bagaimanapun kebijakan subsidi pupuk ini memang masih dilaksanakan di negara berkembang karena suatu penelitian juga menunjukkan bahwa pengurangan subsidi pupuk akan menurunkan produksi beras sebesar 4 persen dan pengurangan keuntungan petani sebesar 40 persen yang tentunya hal ini akan mengancam kondisi ketahanan pangan suatu negara (Wijetunga dan Saito 2017).

Selain ketahanan pangan, dalam SDG's juga terdapat tujuan global yakni mengentaskan kemiskinan (No Poverty). Persentase penduduk miskin di Indonesia menunjukkan untuk wilayah perkotaan sebesar 7,8 persen dan di pedesaan sebesar 13,2 persen. Hal ini merupakan fakta yang miris karena justru kemiskinan lebih banyak di pedesaan yang notabene sebagian besar penduduk pedesaan adalah petani yang menjadi pelaku sentral dalam menggapai kondisi ketahanan pangan (BPS Indonesia 2020).

Fakta kemiskinan di pedesaan tersebut di atas tentu saja tidak terlepas dari pengaruh tingkat pendapatan petani. Kemiskinan yang masih tinggi mengisyaratkan bahwa pendapatan petani masih sangat rendah meskipun di sisi input produksi sudah memperoleh subsidi dari pemerintah. Bagaimanapun pencapaian ketahanan pangan bagi masyarakat di suatu negara harus diimbangi dengan kesejahteraan petani sebagai produsen utama bahan pangan. Oleh karenanya penulis tertarik untuk mengkaji bagaimana dampak kebijakan subsidi terhadap harga komoditas/bahan pangan yang akan berpengaruh pada pendapatan usahatani serta bagaimana pula dampaknya terhadap kesejahteraan petani.

\section{METODE PENELITIAN}

Metode analisis yang digunakan adalah regresi linier berganda untuk mengestimasi hubungan variabel tidak bebas dengan variabel bebas dan arah hubungan tersebut. Analisis pengaruh nilai subsidi energi dan non energi dilakukan menggunakan dua model regresi linier. Nilai subsidi energi dan subsidi energi merupakan variabel bebas, sedangkan variabel tidak bebas yaitu Harga Gabah Kering Panen (GKP) dan Nilai Tukar Petani (NTP).

Pengaruh subsidi energi dan subsidi non energi terhadap harga GKP diprediksi dengan model sebagai berikut:

$$
Y_{i 1}=\beta_{0}+\beta_{1} X_{i 1}+\beta_{2} X_{i 2}+\varepsilon_{i}
$$

$Y_{i 1}$ : Variabel tidak bebas (harga GKP dalam Rp/kg)

$X_{i 1}$ : Variabel bebas (subsidi energi dalam Rp)

$X_{i 2}$ : Variabel bebas ( subsidi non energi dalam Rp) 
$\beta \quad$ : Parameter regresi

$\varepsilon_{i} \quad$ : Variabel gangguan (residu)

Pengaruh subsidi energi dan subsidi non energi terhadap Nilai Tukar Petani (NTP) diprediksi dengan model sebagai berikut:

$$
Y_{i 2}=\beta_{0}+\beta_{1} X_{i 1}+\beta_{2} X_{i 2}+\varepsilon_{i}
$$

$Y_{i 2}$ : Variabel tidak bebas (NTP dalam indeks)

$X_{i 1}$ : Variabel bebas (subsidi energi dalam Rp)

$X_{i 2}$ : Variabel bebas ( subsidi non energi dalam Rp)

$\beta \quad$ : Parameter regresi

$\varepsilon_{i} \quad$ : Variabel gangguan (residu)

Model regresi linier dalam bentuk matriks yaitu sebagai berikut:

$Y=\beta X+\varepsilon$

$$
Y=\left[\begin{array}{c}
Y_{1} \\
Y_{2} \\
\vdots \\
Y_{n}
\end{array}\right]
$$

$X=\left[\begin{array}{ccccc}1 & X_{11} & X_{12} & \ldots & X_{1 k} \\ 1 & X_{21} & X_{22} & \ldots & X_{2 k} \\ \vdots & \vdots & \vdots & \vdots & \vdots \\ 1 & X_{n 1} & X_{n 2} & \ldots & X_{n k}\end{array}\right]$

$\beta=\left[\begin{array}{c}\beta_{0} \\ \beta_{1} \\ \vdots \\ \beta_{k}\end{array}\right]$

$\varepsilon=\left[\begin{array}{c}\varepsilon_{1} \\ \varepsilon_{2} \\ \vdots \\ \varepsilon_{k}\end{array}\right]$

Metode kuadrat terkecil digunakan untuk mengestimasi parameter model regresi dan memerlukan pemenuhan asumsi klasik. Metode kuadrat terkecil merupakan taksiran melalui jumlah kuadrat residual $(\varepsilon)$ yang minimum. Jumlah kuadrat residual dirumuskan sebagai berikut:

$I=\sum_{i=1}^{n} e_{i}^{2}=\sum_{i=1}^{n}\left(y_{i}-\hat{y}_{i}\right)^{2} ; i=1,2, \ldots, n$

Penduga kuadrat terkecil $\beta$ yaitu:

$$
\hat{\beta}=\left(X^{\prime} X\right)^{-1} X^{\prime}
$$

Sehingga, estimasi $\hat{\beta}_{1}$ dan $\hat{\beta}_{0}$

$$
\begin{gathered}
\hat{\beta}_{1}=\frac{\sum x_{i} y_{i}-\frac{\left(\sum x_{i} y_{i}\right)\left(\sum y_{i}\right)}{n}}{\sum x_{i}^{2}-\frac{\left(\sum x_{i}\right)^{2}}{n}} \\
\hat{\beta}_{0}=\bar{y}-b_{1} \bar{x}
\end{gathered}
$$

Maka estimasi regresi linier

$$
\hat{y}_{i}=\hat{\beta}_{0}+\hat{\beta}_{1} x_{1}+\hat{\beta}_{2} x_{2}+\varepsilon
$$

Nilai $\hat{\beta}_{0}$ merupakan pendugaan $b_{0}$ dan nilai $\hat{\beta}_{1}$ pendugaan dari $b_{1}$, sehingga nilai $a, b_{1}$, dan $b_{2}$ diperoleh menggunakan rumus :

$$
\begin{gathered}
a=\bar{Y}-b_{1} \bar{X}_{1}-b_{2} \bar{X}_{2} \\
b_{1}=\frac{\left(\sum x_{2}{ }^{2}\right)\left(\sum x_{1} y\right)-\left(\sum x_{1} x_{2}\right)\left(\sum x_{2} y\right)}{\left(\sum x_{1}{ }^{2}\right)\left(\sum x_{2}{ }^{2}\right)-\left(\sum x_{1} x_{2}\right)^{2}} \\
b_{2}=\frac{\left(\sum x_{1}^{2}\right)\left(\sum x_{2} y\right)-\left(\sum x_{1} x_{2}\right)\left(\sum x_{1} y\right)}{\left(\sum x_{1}{ }^{2}\right)\left(\sum x_{2}{ }^{2}\right)-\left(\sum x_{1} x_{2}\right)^{2}} \\
\text { Koefisien determinasi pada }
\end{gathered}
$$

regresi linier berganda merupakan kontribusi variabel bebas dalam menjelaskan variabel tidak bebas. Menurut Sugiarti dan Megawarni (2012) koefisien determinasi mengestimasi kesesuaian model dengan data. Koefisien determinasi bernilai $0<R^{2}<1$. Formula koefisien determinasi adalah sebagai berikut: 


$$
R^{2}=\frac{S S_{\text {between }}}{S S_{\text {total }}}
$$

SS adalah sum of squared residuals. Variasi yang dijelaskan oleh model yaitu perbandingan total sum of squares dengan residual sum of squares yang disebut between groups sum of squares atau regression sum of squares $\left(S S_{\text {between }}\right.$ atau $\left.S S_{\text {regression }}\right)$ (Miles 2014). Asumsi yang harus dipenuhi dalam regresi linier antara lain yaitu tidak terdapat autokorelasi antara residual atau error yang saling bebas maka kovarian $\left(\varepsilon_{i}, \varepsilon_{j}\right)=0, i \neq j, \quad$ tidak terjadi multikolinearitas atau korelasi antara variabel-variabel bebas dinyatakan dengan $\operatorname{cov}\left(x_{i}, x_{j}\right)=0, i \neq j, \quad$ variabel bebas konstan dalam sampling, dan homokedastisitas yang merupakan ragam residual homogen setiap nilai $x$ dinyatakan dengan $\mathrm{E}\left(\varepsilon_{i}^{2}\right)=\operatorname{var}(\varepsilon)=\sigma^{2}$, rata-rata residual atau error bernilai nol $E\left(\varepsilon_{i}\right)=0, i=1,2, \ldots, n$ dengan varian residual diinyatakan dalam $\left(\varepsilon_{i}\right)=$ $E\left(\varepsilon_{i}^{2}\right)=\sigma^{2}$, dan residual atau error yang mengikuti distribusi normal dengan ratarata nol dan varian $\sigma^{2}$ maka $\varepsilon_{i} \sim N\left(0 ; \sigma^{2}\right)$. Uji dalam regresi linier terdiri dari uji t dan uji F. Statistik uji t adalah sebagai berikut:

$$
t_{h i t}=\frac{b_{j}-\beta_{j}}{S_{b j}}
$$

Maka dapat disusun hipotesis:

$$
\begin{aligned}
H_{0}=\beta_{j}=0 \quad: & \text { Variabel bebas } \\
& x_{j} \text { tidak berpengaruh } \\
& \text { terhadap } Y
\end{aligned}
$$

$$
\begin{aligned}
H_{0}=\beta_{j} \neq 0: & \text { Variabel bebas } x_{j} \\
& \text { berpengaruh } \\
& \text { terhadap } Y
\end{aligned}
$$

Uji $F$ diterapkan pada model secara keseluruhan yaitu pengaruh variabel bebas terhadap variabel tidak bebas secara simultan. Uji F dirumuskan sebagai berikut :

$$
F_{\text {hitung }}=\frac{R 2 / k}{(1-R 2)(n-k-1)}
$$

$\mathrm{R}$ merupakan koefisien regresi, $\mathrm{k}$ adalah jumlah variabel tidak bebas dan $n$ adalah jumlah anggota sampel. Hipotesis pada uji F yaitu:

$$
H_{0}: \beta_{1}=\beta_{1}=\cdots=\beta_{k}=0
$$

(Variabel bebas $x_{k}$ tidak berpengaruh terhadap $Y$ secara simultan)

$$
H_{1}=\min \text { ada satu }=\beta_{j} \neq 0, \mathrm{j}=1,2, \ldots, \mathrm{k}
$$

(Variabel bebas $x_{k}$ berpengaruh terhadap $Y$ secara simultan).

\section{HASIL DAN PEMBAHASAN}

\section{Gambaran Umum Subsidi, Harga Gabah Dan Kesejahteraan Petani}

Anggaran subsidi pemerintah Indonesia yang meliputi subsidi energi dan non energi mengalami perubahan setiap tahun. Rentang tahun 2010-2020 jumlah anggaran subsidi energi tertinggi pada tahun 2014 dan mengalami penurunan yang jauh pada tahun 2015 yaitu Rp 341,8 triliun Rupiah menjadi Rp 119,1 triliun Rupiah. Pengeluaran subsidi 
DAMPAK SUBSIDI TERHADAP HARGA GABAH

DAN KESEJAHTERAAN PETANI

Cici Aulia Permata Bunda, Octaviana Helbawanti, dan Faqihuddin

terendah yaitu pada tahun 2017 dengan jumlahnya lebih rendah dibanding jumlah $\operatorname{Rp} 89,9$ triliun Rupiah. pengeluaran subsidi energi.

Pengeluaran untuk subsidi non energi

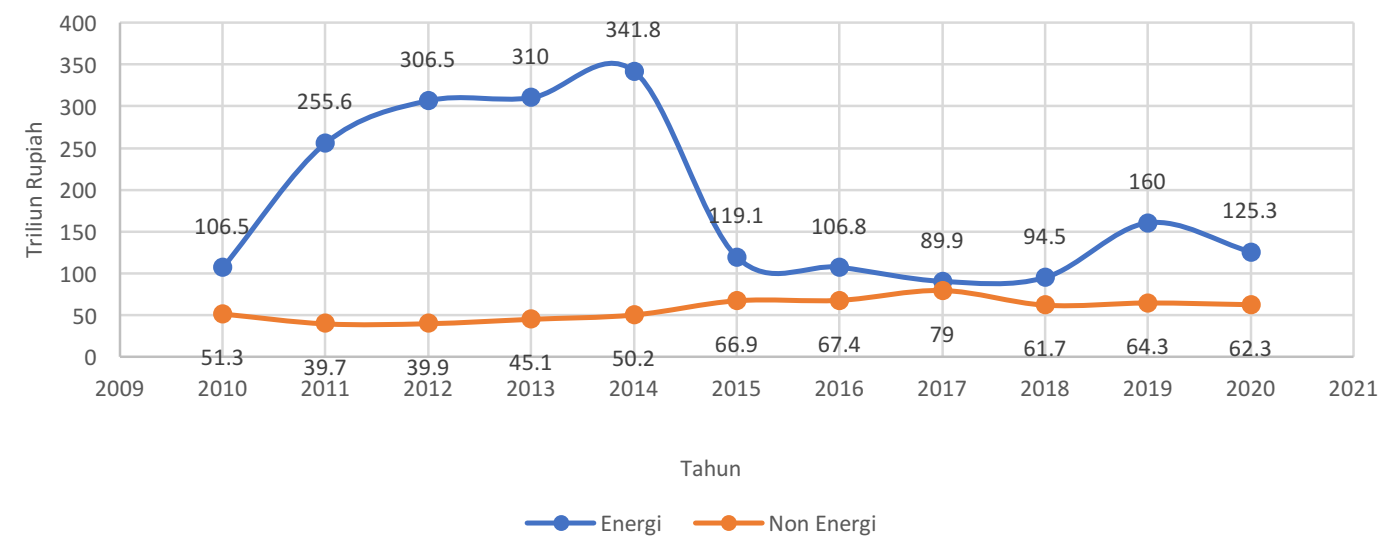

Gambar 1. Grafik Perkembangan Subsidi Energi dan Non Energi Indonesia Tahun 2010-2020

Sementara itu Harga Gabah 4264.82,00. Pada tiga tahun terakhir Kering Panen (GKP) cenderung harga gabah mengalami penurunan meningkat pada periode tahun 2010- sampai pada tahun 2020. Harga gabah 2020. Rata-rata harga gabah selama tertinggi dicapai pada tahun 2018.

tahun 2010 sampai 2020 yaitu Rp

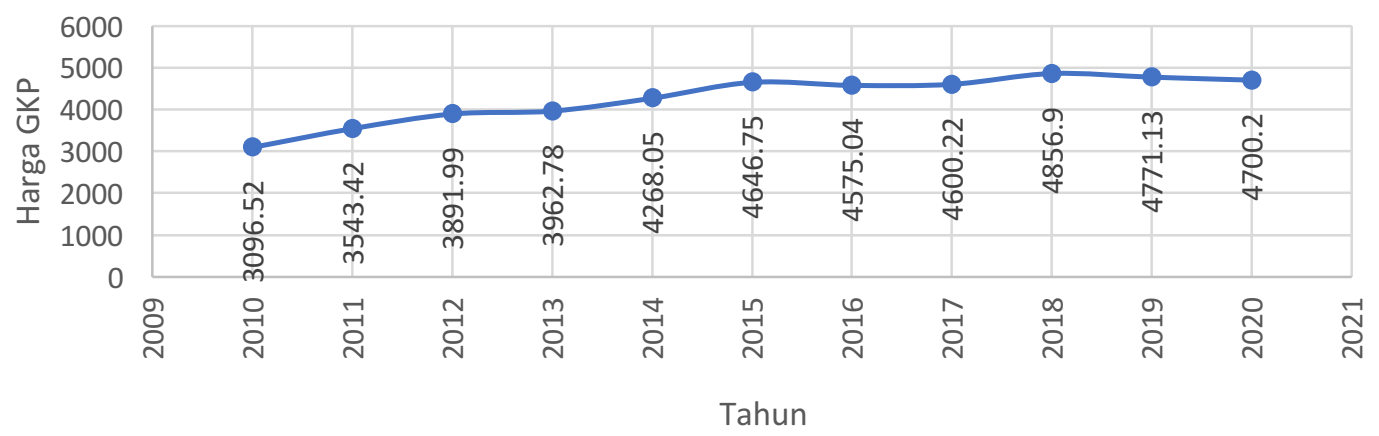

Gambar 2. Grafik Harga GKP Tahun 2010-2020

Pada Gambar 3. NTP Tanaman

Pangan Indonesia bergerak di kisaran 80 sampai 105. Indeks NTP Tanaman pangan tertinggi tercapai pada tahun 2019, sedangkan NTP tanaman pangan terendah berada di tahun 2013. NTP tanaman pangan cenderung mengalami kenaikan mulai tahun 2014, meskipun dua tahun setelah nya mengalami penurunan. NTP Tanaman pangan mengalami penurunan dari tahun 2019 ke tahun 2020 di mana pandemi Covid-19 memiliki peran terhadap nilai tersebut. 


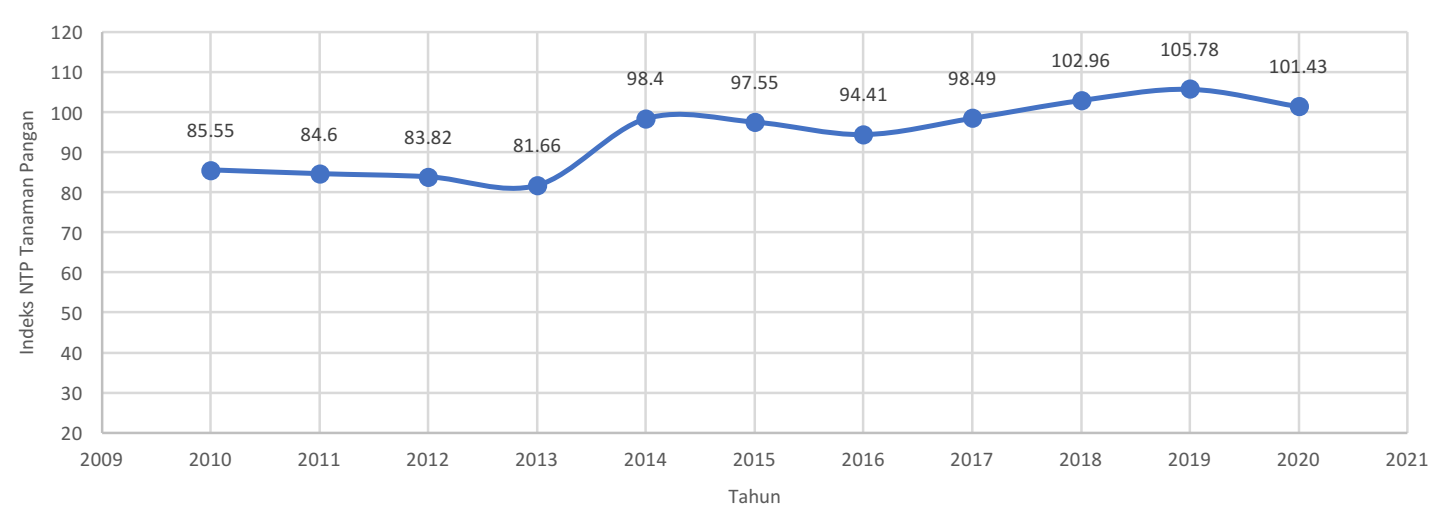

Gambar 3. Grafik Indeks NTP Petani Tanaman Pangan Indonesia Tahun 2010-2020

\section{Hasil uji statistika dampak subsidi}

\section{terhadap harga gabah}

Dampak atau pengaruh Subsidi

Energi dan Non Energi terhadap Harga

Gabah dimodelkan sebagai berikut:

$$
\begin{gathered}
\text { GKP }=1,245573+1,350867 \text { NONENERGI } \\
+0,306890 \text { ENERGI }+\varepsilon
\end{gathered}
$$

Tabel 1. Uji Statistika Dampak Subsidi Terhadap Harga Gabah

\begin{tabular}{lccc}
\hline Variabel & Koefisien & t-statistic & Prob. \\
\hline NONENERGI & 1,350867 & 4,225232 & $0,0029^{* * *}$ \\
ENERGI & 0,306890 & 2,195689 & $0,0594^{*}$ \\
\hline
\end{tabular}

Probabilitas variabel subsidi non energi yang dinotasikan NONENERGI adalah 0,0029 lebih kecil dari alpha 0,01 maka subsidi non energi berpengaruh signifikan terhadap harga gabah (GKP). Probabilitas variabel subsidi energi yang dinotasikan ENERGI adalah 0,0594 lebih kecil dari alpha 0,1 maka subsidi energi berpengaruh signifikan terhadap harga gabah (GKP). Uji $F$ yang signifikan ditunjukkan dari nilai Prob.(F-statistic) yaitu $0,004794<$ alpha 0,05 maka variabel bebas subsidi energi dan non energi berpengaruh signifikan secara simultan terhadap harga gabah (GKP). Nilai $R$ squared model regresi adalah 0,736870 artinya kemampuan kontribusi atau varians kontribusi variabel bebas (subsidi energi dan non energi) sebesar $73 \%$ sedangkan $27 \%$ dijelaskan oleh varibel lain.

Sementara itu hasil uji normalitas menggunakan Jarque Bera menunjukkan nilai probabilitas 0,856797 lebih besar dari alpha 0,05 maka data terdistribusi normal. Sedangkan nilai centered VIF (Tabel 2) pada variabel bebas subsidi NONENERGI dan ENERGI adalah 2,954831 lebih kecil dari 10 maka model estimasi tidak terjadi multikolinearitas. 
DAMPAK SUBSIDI TERHADAP HARGA GABAH

DAN KESEJAHTERAAN PETANI

Cici Aulia Permata Bunda, Octaviana Helbawanti, dan Faqihuddin

Tabel 2. Uji Multikolinearitas Variance Inflation Factors (VIF)

\begin{tabular}{lccc}
\hline \multicolumn{1}{c}{ Variable } & Coefficient Variance & Uncentered VIF & Centered VIF \\
\hline C & 3,644824 & 2212.809 & NA \\
NONENERGI & 0,102217 & 1006.339 & 2.954831 \\
ENERGI & 0,019536 & 309.3731 & 2.954831 \\
\hline Sumber: Data Sekunder Diolah, 2021
\end{tabular}

Nilai uji heterokedastisitas adalah Model yang tidak terjadi

0,2882 lebih besar dari nilai alpha 0,05 heterokedastisitas maka tidak terjadi artinya tidak signifikan maka model ketidaksamaan varian dari residual pada estimasi tidak terjadi heterokedastisitas. pengamatan model regresi.

Tabel 3. Uji Heterokedastisitas Breusch Pagan Godfrey

\begin{tabular}{lcc}
\hline & Indikator & Nilai \\
\hline F-statistic & 4.392838 \\
Obs*R-squared & 5.757435 \\
Scaled explained SS & 2.488314 \\
Prob.F(2,8) & 0.0516 \\
Prob. Chi-Square(2) & 0.0562 \\
Prob. Chi-Square(2) & 0.2882 \\
\hline
\end{tabular}

Sumber: Data Sekunder Diolah, 2021

Uji autokorelasi menggunakan

Breusch-Godfrey Serial Correlation LM

Test menunjukkan nilai lebih besar dari

Tabel 3. Uji Autokorelasi Breusch-Godfrey Serial Correlation LM Test

\begin{tabular}{lc}
\multicolumn{1}{c}{ Indikator } & Nilai \\
\hline F-statistic & 0.170941 \\
Obs ${ }^{R}$-squared & 0.592993 \\
Prob.F(2,6) & 0.8468 \\
Prob. Chi-Square(2) & 0.7434 \\
\hline
\end{tabular}

Sumber : Data Sekunder Diolah, 2021

Hasil uji statistika dampak subsidi terhadap kesejahteraan petani

Selanjutnya untuk mengkaji

Pengaruh Subsidi Energi dan Non Energi alpha 0,05 yaitu 0,7434 , sehingga dapat dinyatakan bahwa model estimasi bebas dari autokorelasi.

Tabel 4. Uji Statistika Dampak Subsidi Terhadap Kesejahteraan Petani

\begin{tabular}{lccc}
\hline \multicolumn{1}{c}{ Variabel } & Koefisien & t-statistic & Prob. \\
\hline NONENERGI & 39,89409 & 2,884235 & $0,0204^{\star *}$ \\
ENERGI & 5,886146 & 0,973426 & 0,3589 \\
\hline
\end{tabular}

Dalam estimasi terhadap NTP Tanaman Pangan, variabel bebas yang signifikan berpengaruh adalah subsidi non energi yang dinyatakan dalam notasi NONENERGI. Signifikansi dilihat dari nilai terhadap Nilai Tukar Petani (NTP) sektor tanaman pangan dimodelkan sebagai berikut:

NTPPANGAN $=-96,27523+39,89409$ NON $E N E R G I+5,886146 E N E R G I+\varepsilon$ 
signifikan terhadap NTP tanaman pangan. Nilai Prob(F-statistic) menunjukkan uji $F$ signifikan yaitu 0,017855<alpha 0,05 maka variabel subsidi energi dan non energi berpengaruh signifikan secara simultan terhadap NTP. Nilai R squared model regresi adalah 0,634456 dapat diartikan bahwa variabel bebas yang dianalisis yaitu subsidi energi dan non energi memiliki kontribusi sebesar $63 \%$ dalam menjelaskan variabel tidak bebas (NTP), sehingga $37 \%$ dijelaskan oleh variabel lain. Sementara itu nilai Probabilitas Jarque-Bera pada estimasi NTP adalah 0,699238 maka sebaran data terdistribusi normal. Probabilitas Jarque-Bera lebih dari alpha 0,05 artinya tidak signifikan. Data yang memenuhi sebaran normal maka data merata tidak condong ke kanan atau ke kiri.

Tabel 5. Uji Multikolinearitas Variance Inflation Factors (VIF)

\begin{tabular}{lccc}
\hline \multicolumn{1}{c}{ Variable } & $\begin{array}{c}\text { Coefficient } \\
\text { Variance }\end{array}$ & Uncentered VIF & Centered VIF \\
\hline C & 6821.951 & 2212.809 & NA \\
NONENERGI & 191.3180 & 1006.339 & 2.954831 \\
ENERGI & 36.56424 & 309.3731 & 2.954831 \\
\hline
\end{tabular}

Sumber : Data Sekunder Diolah, 2021

Model estimasi bebas dari dari 10 pada variabel bebas subsidi multikolinearitas ditunjukkan dari nilai energi dan non energi.

Variance Inflation Factors (VIF) kurang

Tabel 6. Uji Heterokedastisitas Breusch Pagan Godfrey

\begin{tabular}{lc}
\multicolumn{1}{c}{ Indikator } & Nilai \\
\hline F-statistic & 0.474813 \\
Obs*R-squared & 1.167188 \\
Scaled explained SS & 0.232923 \\
Prob.F(2,8) & 0.6385 \\
Prob. Chi-Square(2) & 0.5579 \\
Prob. Chi-Square(2) & 0.8901 \\
\hline
\end{tabular}

Sumber : Data Sekunder Diolah, 2021

tidak signifikan, sehingga model estimasi

Nilai Prob. Chi-Square(2) yaitu

terhadap

NTP bebas

dari

0.8901 lebih besar dari alpha 0,05 maka

heterokedastisitas.

Tabel 7. Uji Autokorelasi Breusch-Godfrey Serial Correlation LM Test

\begin{tabular}{lc}
\hline \multicolumn{1}{c}{ Indikator } & Nilai \\
\hline F-statistic & 0.138590 \\
Obs $^{*} R$-squared & 0.485725 \\
Prob.F(2,6) & 0.8733 \\
Prob. Chi-Square(2) & 0.7844 \\
\hline Sumber:
\end{tabular}

Sumber: Data Sekunder Diolah, 2021

Nilai Prob. Chi-Square(2) pada tes

Godfrey Serial Correlation LM Test lebih autokorelasi menggunakan Breuschbesar dari alpha 0,05 yaitu 0,7844 . Nilai 
DAMPAK SUBSIDI TERHADAP HARGA GABAH

DAN KESEJAHTERAAN PETANI

Cici Aulia Permata Bunda, Octaviana Helbawanti, dan Faqihuddin

probabilitas yang lebih besar dari alpha atau tidak signifikan maka pada model tidak terjadi autokorelasi.

\section{Pembahasan dampak subsidi terhadap} harga gabah dan kesejahteraan petani

Pemberian subsidi pada petani dapat menurunkan harga jual produk dan meningkatkan permintaan, sehingga subsidi berperan dalam mekanisme pasar. Permintaan dan penawaran di pasar pada titik ekuilibrium membentuk harga barang dan jasa pada titik P1.

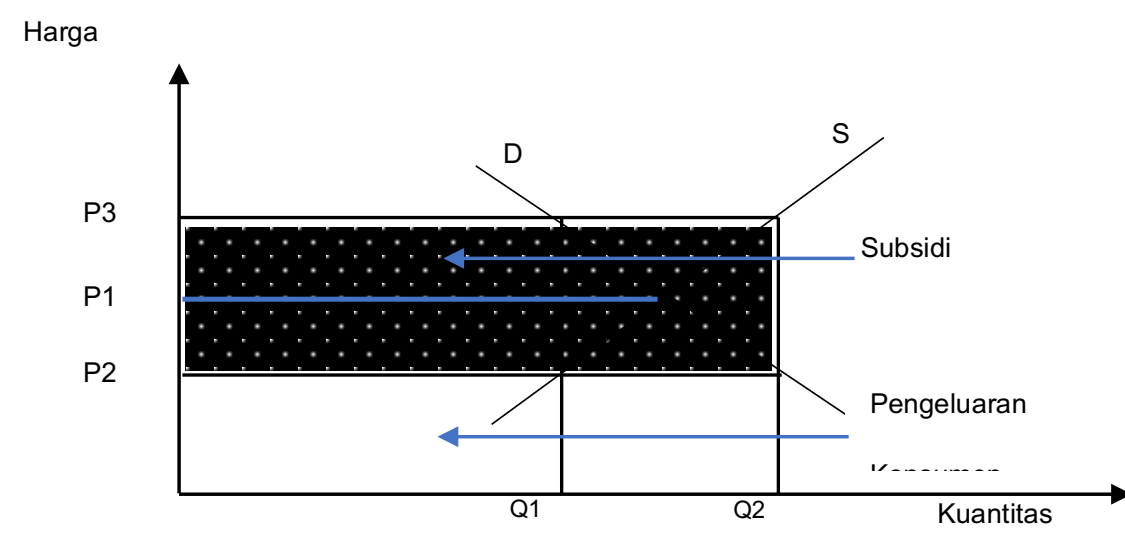

Gambar 4. Subsidi dan pembentukan harga.

Namun demikian, dari hasil pengujian statistika di atas kita dapat mengetahui bahwa subsidi pemerintah (subsidi energi dan non energi) secara simultan memberikan pengaruh terhadap harga gabah (GKP) dan NTP. Namun jika kita bandingkan Nilai $R$ squared model regresi atau yang biasa kita sebut sebagai koefisien determinasi $\left(R^{2}\right)$, terlihat bahwa $\mathrm{R}^{2}$ susbsidi dengan harga adalah sebesar $73 \%$ sedangkan subsidi dengan NTP hanya $63 \%$. Subsidi pemerintah (subsidi energi dan non energi) yang lebih cenderung pada subsidi input, lebih besar
Produsen memperoleh harga jaminan pasar atas penjualan barang dan jasa mencapai P3. Pada kuantitas atau volume Q2 dan konsumsi pada Q1 maka harga dapat turun ke titik P2 dengan adanya subsidi. Nilai kompensasi atau subsidi merupakan selisih harga P3 dan $\mathrm{P} 2$, sehingga konsumen diuntungkan dari penurunan harga tersebut dan produsen dapat mengalami kenaikan produksi atau penawaran. 
menyatakan bahwa terdapat pengaruh pemberian fasilitas pupuk bersubsidi terhadap pembelian pupuk komersial. Pembelian pupuk komersial dapat berkurang karena program subsidi input berkontribusi terhadap ketahanan pangan rumah tangga dan kemampuan membeli bahan pangan, meningkatkan penawaran, dan menurunkan biaya produksi. Penurunan penggunaan pupuk komersial juga dianalisis oleh Mason dan Jayne (2013). Pupuk bersubsidi memiliki pengaruh pada pengeluaran atau biaya input pada penggunaan faktor produksi. (Solaymani $d k k$. 2019) menjelaskan bahwa subsidi pupuk dapat berdampak pada kondisi perekonomian negara melalui performa sektor pertanian. Seperti yang dijelaskan oleh Liang $d k k$. (2019) yaitu peningkatan pendapatan melalui efisiensi penggunaan input. Hal tersebut juga ditunjukkan pada penelitian Ramli dkk. (2012) bahwa usahatani padi sangat terpengaruh dengan adanya intervensi subsidi dalam peningkatan panen, keberlanjutan produksi, swasembada, dan mengurangi ketergantungan ekspor.

$$
\text { Sementara itu, subsidi energi }
$$
berupa bahan bakar berpengaruh terhadap kemampuan rumah tangga pada keterjangkauan harga beli barang dan jasa. Penurunan harga bahan bakar dan listrik dapat menimbulkan ketimpangan jika kelas pendapatan menengah ke atas ikut mengkonsumsi secara dominan. Pengaruh subsidi energi terhadap kesejahteraan secara langsung yaitu terhadap aktivitas memasak dan rumah tangga, lampu, dan transportasi pribadi, sedangkan dampak secara tidak langsung yaitu pada kenaikan faktor produksi dan harga konsumen (Coady dan Arze del Granado 2010). Menurut Badiani et al. (2012) subsidi energi terutama listrik berperan pada pemanfaatan ekstraksi air tanah pada proses irigasi. Dampak tersebut menjadi perdebatan jika dilihat dari sisi keberlanjutan lingkungan meskipun positif terhadap peningkatan pendapatan dan pertumbuhan ekonomi desa. Hal ini seperti yang dipaparkan oleh Lin dan Jiang (2011) bahwa terdapat gap antara harga aktual konsumsi energi dengan harga konsumsi akhir tanpa subsidi. Subsidi berperan pada kesejahteraan sosial, insentif pengiriman dan konsumsi yang efisien, tetapi harus dipertimbangkan dampak terhadap kelangkaan dan isu lingkungan. Subsidi energi menurut Lin dan Kuang (2020) berdampak pada aktivitas pemenuhan pangan, pakaian, perumahan, layanan kesehatan, pendidikan, sosial budaya, dan rekreasi.

\section{KESIMPULAN}

Dari hasil dan pembahasan dapat disimpulkan bahwa kebijakan subsidi pemerintah berdampak pada harga 


\section{DAMPAK SUBSIDI TERHADAP HARGA GABAH}

DAN KESEJAHTERAAN PETANI

Cici Aulia Permata Bunda, Octaviana Helbawanti, dan Faqihuddin

gabah (GKP) dan juga kesejahteraan

petani. Namun demikian, dilihat dari koefisien determinasi nampak bahwa dampak subsidi pemerintah terhadap harga gabah $(73 \%)$ lebih besar dari pada dampak subsidi terhadap kesejahteraan petani yakni hanya $63 \%$ (masih ada faktor lain selain subsidi sebesar $37 \%$ yang mempengaruhi kesejahteraan petani). Oleh karena itu, dalam rangka perbaikan kesejahteraan petani (sebagai pelaku utama pembangunan pertanian) penulis memandang bahwa kebijakan subsidi yang bersifat subsidi input perlu diimbangi dengan kebijakan insentif lain bagi petani maupun penyesuaian subsidi input tersebut ke dalam bentuk lain.

\section{DAFTAR PUSTAKA}

Andini MS. 2020. Analisis Ringkas Cepat DPR RI: Tantangan dan Perkembangan Kebijakan Anggaran Subsidi Pupuk.

Badiani R, Jessoe KK, Plant S. 2012. Development and the Environment: The Implications of Agricultural Electricity Subsidies in India. J Environ Dev. 21(2):244-262. doi:10.1177/1070496512442507.

BPS Indonesia. 2020. STATISTIK Profil Kemiskinan di Indonesia.

Coady D, Arze del Granado J. 2010. The Unequal Benefits of Fuel Subsidies: A Review of Evidence for Developing Countries.

Hussain A, Khan MA, Ali Buttar MA, Farooq U, Islam M, Khan ZU. 2018. Revising fertilizer subsidy and taxes policy for reducing cost of production of major crops in Pakistan. Sarhad J Agric.
34(4):870-879.

doi:10.17582/journal.sja/2018/34.4. 870.879 .

Liang $L$, Wang $Y$, Ridoutt BG, Lal $R$, Wang D, Wu W, Wang L, Zhao G. 2019. Agricultural subsidies assessment of cropping system from environmental and economic perspectives in North China based on LCA. Ecol Indic. 96(September 2018):351-360. doi:10.1016/j.ecolind.2018.09.017.

Lin B, Jiang Z. 2011. Estimates of energy subsidies in China and impact of energy subsidy reform. Energy Econ. 33(2):273-283. doi:10.1016/j.eneco.2010.07.005.

Lin B, Kuang Y. 2020. Household heterogeneity impact of removing energy subsidies in China: Direct and indirect effect. Energy Policy. 147(July):111811. doi:10.1016/j.enpol.2020.111811.

Mason NM, Jayne TS. 2013. Fertiliser subsidies and smallholder commercial fertiliser purchases: Crowding out, leakage and policy implications for Zambia. J Agric Econ. 64(3):558-582. doi:10.1111/1477-9552.12025.

Mather DL, Jayne TS. 2018. Fertilizer subsidies and the role of targeting in crowding out: evidence from Kenya. Food Secur. 10(2):397-417. doi:10.1007/s12571-018-0773-8.

Miles J. 2014. $R$ Squared, Adjusted $R$ Squared. In: Wiley StatsRef: Statistics Reference Online. p. 2-4.

Mulyadiana AT, Marwanti S, Rahayu W. 2018. Analysis of the effectiveness of fertilizer subsidy policy and its effect on rice production in Karanganyar Regency. IOP Conf Ser Earth Environ Sci. 142(1). doi:10.1088/17551315/142/1/012047.

Nasrin M, Bauer S, Arman M. 2018. Assessing the impact of fertilizer subsidy on farming efficiency: $A$ 
case of Bangladeshi farmers. Open Agric. 3(1):567-577. doi:10.1515/opag-2018-0060.

Priyadi R, Nuryati R, Faqihuddin F. 2020. The Household Welfare Level of Integrated Plantation Polyculture Farmers. In: IOP Conference Series: Earth and Environmental Science. Vol. 466.

Ramli NN, Shamsudin MN, Mohamed Z, Radam A. 2012. The Impact of Fertilizer Subsidy on Malaysia Paddy/Rice Industry Using a System Dynamics Approach. Int J Soc Sci Humanit. 2(3):213-219.

Solaymani S, Aghamohammadi E, Falahati A, Sharafi S, Kari F. 2019.
Food security and socio-economic aspects of agricultural input subsidies. Rev Soc Econ. 77(3):271-296. doi:10.1080/00346764.2019.15962 98.

Sugiarti H, Megawarni A. 2012. Konsistensi koefisien determinasi sebagai ukuran kesesuaian model pada regresi robust. J Mat Sains, dan Teknol. 13(2):65-72.

Wijetunga CS, Saito K. 2017. Evaluating the Fertilizer Subsidy Reforms in the Rice Production Sector in Sri Lanka: A Simulation Analysis. Adv Manag Appl Econ. 7(1):31-51. 